\title{
O DISCURSO CITADO NO TEXTO LITERÁRIO
}

\section{THE DISCOURSE OF SOMEONE IN THE LITERARY TEXT}

CLEIDE INÊS WITTKE *

RESUMO: O dizer do outro está presente em nosso cotidiano, nas falas comuns, na mídia e de modo especial no discurso literário. Nesse contexto e sob uma ótica polifônica bakhtiniana (1981, 1992), este artigo tem o objetivo de compreender como o discurso do outro, mostrado ou constitutivo, segundo Authier-Revuz $(1982,1998)$, manifesta-se no dizer literário. Selecionamos, então, três crônicas publicadas em um jornal de circulação estadual no Rio Grande do Sul e investigamos o funcionamento das estratégias linguístico-discursivas que mostram ou encobrem a fala do outro, produzindo efeitos de sentido nos textos analisados. Buscamos entender os diferentes usos dos discursos direto, indireto e indireto livre, e também de outros indicadores, relacionando-os com o dizer do narrador que ora aproxima-se, ora afasta-se da voz alheia, dependendo do efeito de sentido almejado.

PALAVRAS-CHAVE: Crônica. Voz Mostrada ou Velada. Abordagem Discursiva Bakhtiniana.

* Docente da UFPEL - Universidade Federal de Pelotas. E-mail cleideinesw@yahoo.com.br. 
ABSTRACT: Other people's voices are part of our daily lives, in usual talks, in the media, and mainly in the literary discourse. Bearing this in mind and under the bakhtinian polyphonic perspective $(1981,1982)$ this paper aims at understanding in which ways someone else's speech, either overt or covert, according to Authier-Revuz (1982, 1998), is present in literary works. We have chosen three articles published in a newspaper distributed in the state of Rio Grande do Sul and analyzed the linguistic and discursive strategies that overt or covert the interlocutor's speech, producing meaning in the literary texts. We have tried to understand the uses of direct speech, indirect speech and free indirect speech, as well as other indices, relating them to the narrator's voice, which sometimes gets close and sometimes leads away from the alien voice, depending on the meaning.

KEYWORDS: Chronicle. Clear or Disguised Voice. Bakhtinian Discourse Approach.

\section{Considerações Iniciais}

O discurso do outro, o relatado para Bakhtin (1981, 1992), consiste em um tema já bastante discutido, no entanto, sua complexidade ainda gera muitas investigações no campo da linguagem, tanto na área linguística quanto na literária (BRAIT, 2005). Há consenso de que o discurso de outrem faz parte de nosso dizer cotidiano, da fala retórica, da mídia, da política e também da manifestação literária. E essa voz pode apresentar-se tanto de modo explícito quanto velado, o fundamental é que está lá, marcada ou não, produzindo efeitos de sentido. Nessas condições, este artigo procura identificar 
e também compreender a maneira como o discurso do outro se manifesta na crônica. Para atingir esse objetivo, analisamos várias crônicas do jornal Zero Hora, do Rio Grande do Sul, selecionando três dentre os diversos textos lidos para construir uma reflexão sobre essa temática.

Considerando que o discurso relatado é uma das características do gênero crônica, norteamos nossa investigação com base em dois eixos de análise. 0 primeiro consiste no fato de que às vezes o narrador aproxima-se mais da voz do outro, tornando-a menos marcada; outras vezes afasta-se dela, mostrando-a com nitidez, dependendo do efeito semântico que intenciona produzir. 0 segundo eixo refere-se à questão de que a intervenção do outro acontece através do uso de recursos linguísticos e discursivos tais como aspas, itálico, ironia, ambiguidade, inferência e ainda pelo emprego de diferentes discursos como: direto, indireto, direto livre e indireto livre. Buscamos explicitar de que forma o discurso do outro atua na crônica, investigando quais são os efeitos de sentido produzidos pelo discurso citado, tanto na modalidade explícita quanto na velada. Questionamos quais são os esquemas linguísticos mais usados na narrativa curta e quais efeitos de sentido produzem nesse gênero. A partir das reflexões de Fiorin (2006, p. 170), produzidas com base nos estudos de Bakhtin, entendemos que

[...] formas de incorporação do discurso do outro são a própria maneira de tornar visível esse princípio de funcionamento das unidades reais de comunicação, os enunciados. São modos pelos quais o princípio real de funcionamento da linguagem é enunciado.

Há duas maneiras básicas de incorporar distintas vozes no enunciado:

a) aquela em que o discurso do outro é abertamente citado e 
nitidamente separado; b) aquela em que o enunciado é bivocal, ou seja, internamente dialogizado.

$\mathrm{Na}$ primeira categoria, entram formas composicionais como o discurso direto e o discurso indireto, as aspas, a negação; na segunda, aparecem formas composicionais como a paródia, a estilização, a polêmica velada ou clara; o discurso indireto livre.

Fundamentamos nossa investigação do discurso do outro a partir da abordagem discursiva e polifônica de Bakhtin (1981, 1992), considerando sua reflexão sobre o modo como os discursos direto, indireto e, principalmente, o discurso indireto livre surgiram e foram funcionando na produção literária, passando de um autor com dizer autoritário a uma fala polifônica. Esses discursos, ou melhor, esses esquemas linguísticos operam em função da maior ou menor necessidade de o narrador identificar-se abertamente ou não com o discurso citado. Tal análise remete à origem do termo polifo$\mathrm{nia}^{1}$, que serve como divisor de águas entre o dizer do autor autoritário, enunciador de uma única voz (próprio da obra de Tolstói), e do autor polifônico, carnavalesco, aquele que deixa fluir várias vozes (característica da obra de Dostoiévski, ver Bakhtin, 2002). Fazemos nossas as palavras de Brait, quando a autora explicita que

Para definir o gênero polifônico do romance, e situar sua inovação e seu alcance, Bakhtin analisa, como se observou, a obra toda de Dostoiévski. Ele não tinha um conceito ad hoc de polifonia para testar nos escritos de Dostoiévski. É a partir dos textos de Dostoiévski que o conceito é formulado, constituído. Portanto, essa é sem dúvida uma das caracterís-

1 Segundo Faraco (2009, p. 77), “o termo polifonia, adotado por Bakhtin do vocabulário da música, foi por ele usado para qualificar o projeto estético realizado por Dostoiévski em seus romances da maturidade". 
ticas de uma teoria/análise dialógica do discurso: não aplicar conceitos a fim de compreender um discurso, mas deixar que os discursos revelem sua forma de produzir sentido, a partir de ponto de vista dialógico, num embate. (BRAIT, 2006, p. 23).

Seguindo essa esteira teórica, nosso estudo também se baseia na perspectiva da heterogeneidade constitutiva e mostrada de Authier-Revuz $(1982,1998)$, pois concordamos com o pensamento da autora de que a heterogeneidade é constitutiva na própria natureza da linguagem, podendo estar ou não marcada.

\section{0 discurso alheio na abordagem polifônica de Bakhtin}

Para Bakhtin (1981), o discurso de outrem, o citado, é o discurso no e sobre o discurso; é a enunciação na e sobre a enunciação. Nessa ótica, enquanto aquilo que falamos é o conteúdo propriamente do nosso dizer, o discurso do outro é mais do que isso, pois pode entrar no discurso e na sua construção sintática, produzindo uma unidade integral nessa construção. Assim, segundo Bakhtin (1981, p. 144), "o discurso citado conserva sua autonomia estrutural e semântica sem nem por isso alterar a trama linguística do contexto que integrou". Em vista disso, ao analisar o discurso citado, não podemos nos ater apenas ao seu conteúdo, pois tal análise mostra de que modo o sujeito fala, todavia, só podemos saber o que ele realmente diz, se analisarmos suas palavras, mesmo que seja por meio do discurso indireto.

Na medida em que se integra à enunciação da unidade estrutural do discurso narrado, o discurso citado passa a cons- 
tituir-se como seu tema, pois um tema autônomo torna-se um tema do tema. Dessa forma, o falante vê o discurso citado como a enunciação de outra pessoa, independentemente de sua origem, que possui uma construção completa e está localizada fora do contexto narrativo. 0 discurso do outro passa a fazer parte do contexto narrativo, conservando o seu conteúdo e, em partes, sua integridade linguística de origem; no entanto, ao integrar-se a outra enunciação, ele precisa ajustar-se às regras sintáticas, estilísticas e composicionais, elaboradas pelo dizer em questão, nesse caso, o narrado.

No entender de Bakhtin (1981), o sujeito que apreende a enunciação do outro não é um ser mudo, sem palavra; ao contrário, é um ser pleno de dizeres interiores. Nessas condições, esse sujeito mediatiza sua atividade mental via discurso interior, relacionando-o com o discurso que é apreendido do exterior. Em síntese, a palavra vai à palavra. É, portanto, no discurso interior que o sujeito apreende e aprecia o discurso do outro, em que opera a orientação ativa do falante.

A relação estabelecida entre o discurso citado e o contexto narrativo pode seguir dois princípios: visar à conservação da integridade e autenticidade do discurso de outrem, com fronteiras nítidas; ou, ainda, a diluí-lo no discurso narrado. Quando ocorre a primeira situação, temos o estilo linear, ou seja, os esquemas linguísticos e suas variantes são usados de modo a isolar o discurso citado, protegendo-o da infiltração de entoações do narrador, estabelecendo fronteiras visíveis, o que, para Bakhtin (1981), corresponde a uma fraqueza do fator individual interno. Nesse caso, a apreensão e a transmissão do discurso do outro é linguisticamente despersonalizada e mantida em blocos isolados, separados. 0 autor cita os textos escritos em francês medieval e em russo antigo (século XVII na França e século XVIII na Rússia) como exemplos desses usos. 
Já a segunda situação diz respeito ao estilo pictórico, que é o oposto ao anterior, pois, com caráter bem mais individualizado, nele, "o contexto narrativo esforça-se por desfazer a estrutura compacta e fechada do discurso citado, por absorvê-lo e apagar suas fronteiras." (BAKHTIN, 1981, p. 150). No quadro pictórico, esclarece Bakhtin (1981), há diversos tipos que variam conforme o grau de envolvimento do narrador. Por exemplo, o narrador pode distinguir totalmente as fronteiras do discurso citado, com o intuito de colori-lo com sua própria entoação, com seu humor, sua ironia, sua raiva, sua admiração, seu apego, dentre outras manifestações, o que é característico do Renascimento, no fim do século XVIII e durante quase todo o século XIX. Existe também outro tipo: quando o dominante é o discurso citado, pois ele é mais forte e acaba envolvendo o contexto narrativo em que se enquadra, dissolvendo-o. Um bom exemplo desse uso encontra-se na obra de Dostoiévski. Nesse viés, Faraco (2009, p. 141) defende que se aceita,

[...] por exemplo, atravessar determinado discurso com réplicas, comentários, polêmicas, isto é, admitem-se, na citação, os diversos tipos do estilo que ele (Bakhtin) chama de pictórico - aquele cuja característica principal é atenuar os contornos exteriores nítidos da palavra de outrem? Ou, para usar a terminologia de Bakhtin, o discurso reportante toma o discurso reportado como palavra interna persuasiva? Ou só se aceita citá-lo mantendo a relativa integridade da voz alheia, isto é, só se admitem as diferentes variantes do estilo que Voloshinov chama de linear - aquele cuja tendência principal é criar contornos nítidos à volta do discurso citado; aquele que toma o discurso reportado como palavra de autoridade?

No entender de Bakhtin (1981), há ainda outro modo de expressar o discurso alheio, trata-se da estrutura linguística mista. Essa acontece com o discurso indireto sem sujeito 
aparente, ou, de forma ainda mais complexa, com o uso do discurso indireto livre, na medida em que dilui completamente as fronteiras do discurso citado. E o autor previne que, ao examinar as tendências da apreensão ativa do discurso do outro, deve-se dar atenção a todos os fenômenos linguísticos em questão, principalmente, em relação ao objetivo que o discurso narrado busca alcançar. 0 discurso literário, por sua natureza criativa, é mais livre do que o discurso retórico, na maneira de lidar com a fala do outro. 0 dizer retórico está mais engajado com os direitos de propriedade da palavra e preocupa-se com a questão da autenticidade; em vista disso, tende a lidar com menos liberdade com o discurso do outro.

\subsection{0s esquemas discursivos e suas estruturas sintáticas}

Conforme Bakhtin (1981), existem esquemas básicos que expressam linguisticamente a relação estabelecida entre o discurso citado e o narrado. Esses esquemas realizam-se através de variantes, as quais indicam, por sua vez, a relação de força existente entre o discurso citado e o narrado, em dado momento do desenvolvimento da língua. É, então, nas variantes que encontramos as alterações no modo como determinado grupo social expressa a relação entre o discurso do outro e o do narrador. Nessas condições, o autor defende que essas variantes encontram-se na fronteira da gramática com a estilística. No entender do autor, é muito difícil estabelecer limite entre a gramática e a estilística, ou seja, entre o sistema gramatical e sua variante estilística (FARACO, 2009).

Na perspectiva bakhtiniana, cada esquema expressa determinada tendência à apreensão ativa que faz do discur- 
so do outro. Isto é, cada esquema recria de modo específico a enunciação, atribuindo-lhe uma orientação particular. Por isso não podemos passar de um discurso a outro sem efetuar os devidos ajustes, característicos de cada estrutura sintática. A tendência analítica do discurso indireto sustenta-se no fato de que os elementos emocionais e afetivos desse discurso não podem ser expressos no conteúdo, mas somente nas formas de sua enunciação. As abreviações, elipses, hesitações e outras manifestações emocionais típicas do discurso direto não podem ser expressas no discurso indireto, em função de seu caráter analítico. Dessa forma, as particularidades de construção e de entoação típicas dos enunciados interrogativos, exclamativos e imperativos não são mantidas no discurso indireto, pois se revelam apenas em seu conteúdo. É nesse sentido que Bakhtin (1981, p. 159) diz que "a análise é a alma do discurso indireto".

O autor alerta para a importância de o analista saber diferenciar as duas orientações que a tendência analítica do discurso indireto pode assumir, bem como suas variantes. Vai além e orienta que a voz do outro pode ser apreendida como uma tomada de posição com conteúdo semântico preciso, por parte do falante, via construção indireta, transpondo de modo analítico sua composição objetiva exata, por meio do estilo linear. Mas também pode apreendê-la enquanto expressão que caracteriza tanto o objeto do discurso quanto o próprio falante: seu estado de espírito, seu modo de falar (a fala entrecortada, por exemplo), sua maneira de exprimir-se etc.

O estilo linear apreende a enunciação do outro no plano meramente temático, permanecendo surdo e indiferente a tudo que não possui significação temática. Com o risco de sofrer despersonalização do discurso citado, essa variante abre possibilidade às tendências para a réplica e para o co- 
mentário no contexto narrativo, ao mesmo tempo em que conserva nítida distância entre as palavras do narrador e as do outro (geralmente, de uma personagem). Ainda no que tange à construção indireta, a variante analisadora da expressão integra as palavras e as maneiras de dizer do discurso do outro, que caracterizam a sua configuração subjetiva e estilística enquanto expressão. Na maioria das vezes, esses dizeres são colocados entre aspas, tornando-se visíveis, marcados (cf. AUTHIER-REVUZ, 1982).

Além das duas variantes do discurso indireto (analisadora do conteúdo e da expressão), Bakhtin (1981) identifica uma terceira variante: a impressionista, cuja característica é transmitir o discurso interior, os pensamentos e os sentimentos da personagem no dizer narrado. Essa modalidade encontra-se no meio do caminho entre as duas anteriores. Nesse caso, temos o discurso indireto livre, pois há solidariedade plena entre narrador e personagem, sobrepondo-se uma entoação a outra, fundindo completamente suas vozes, sendo que a fala ora pertence ao discurso de um, ora ao de outro.

Para Bakhtin (1981), Tobler (1887) foi o primeiro autor a referir-se ao discurso indireto livre como citação do discurso, comparando-o com o discurso direto e o indireto. Tobler definiu esse discurso como uma forma que mistura o discurso direto e o indireto, pois enquanto o tom e a ordem das palavras advêm do primeiro, os tempos verbais e as pessoas emergem do segundo. No entanto, Bakhtin não concorda com a perspectiva de Tobler de que, ao relatar acontecimentos passados, o falante introduz a enunciação de um terceiro (um outro), um dizer independente na narrativa. Para Bakhtin, a questão está na diferente inter-relação estabelecida entre o discurso narrado e o discurso citado, criando uma nova forma linguística, esquema que não foi reconhecido por Tobler. 
Conforme Bakhtin (1981), Kalepky também estudou o discurso indireto livre, definindo-o como uma forma autônoma de criar o discurso do outro, e o caracterizou como um discurso oculto ou velado. A significação linguística desse esquema está no fato de que é preciso adivinhar a quem a palavra pertence. $\mathrm{O}$ avanço nos estudos de Kalepky está no fato de conceber o discurso indireto livre como nova orientação estilística positiva e não mais a combinação de dois esquemas sintáticos, como defendia Tobler. Bakhtin reconhece que Kalepky foi feliz ao ver a dualidade nessa forma, mas discorda do teórico quando ele diz ser esse um discurso mascarado e também por ele assumir que a identificação do falante é o aspecto mais importante no discurso. Nesse esquema, o fundamental é que a personagem e o narrador se expressam conjuntamente, em uma única construção, enquanto duas vozes diferentes são ouvidas concomitantemente.

Ao refletir sobre as indagações de Kalepky, em 1914, Bally concebeu o discurso indireto livre na sua forma mais pura, com base nas figuras de pensamento. Do ponto de vista gramatical, é o discurso do narrador, mas, de acordo com o sentido (enquanto fenômeno extralinguístico), é a fala da personagem. Para Bally, o esquema do discurso indireto inclinase ao do discurso direto, funcionando o discurso indireto livre como passagem de um para outro. Ao questionar como surgiu o discurso indireto livre, Bakhtin (1981) esclarece que, no francês antigo, não havia formas lógicas que possibilitassem uma verdadeira diluição do discurso do autor/narrador com o de sua personagem. E foi essa insuficiência gramatical, e não o procedimento estilístico livre, que criou condições para que surgisse o discurso indireto livre. Em resumo, esse discurso foi fruto da incapacidade de o autor/narrador separar gramaticalmente seu ponto de vista do de suas personagens. 
O processo linguístico objetivo do discurso indireto livre combina as entoações da personagem (empatia) e as do narrador (distanciamento) em uma mesma construção linguística. No discurso indireto livre, a palavra citada não é identificada somente pelo sentido isolado, mas pelas entoações específicas da personagem; enfim, pela orientação apreciativa do discurso, especifica Bakhtin. Nessa ótica, o discurso do outro passa a funcionar como no teatro, onde não há contexto narrativo e as réplicas do herói opõem-se às das outras personagens. A relação estabelecida entre o contexto narrativo e o discurso citado, via encenação absoluta, assume características semelhantes à alternância do diálogo, e o narrador se coloca no mesmo nível de sua personagem, assumindo uma relação dialógica. No dizer de Bakhtin (1981, p. 195), “toda a atividade verbal consiste em distribuir 'a palavra de outrem' e a 'palavra que parece ser a de outrem'”. É nesse sentido que Faraco (2009, p. 85), em seus estudos sobre o círculo bakhtiniano, defende que

\begin{abstract}
Nossos enunciados emergem - como respostas ativas que são no diálogo social - da multidão das vozes interiorizadas. Eles são, assim, heterogêneos. Desse ponto de vista, nossos enunciados são sempre discurso citado, embora nem sempre percebidos como tal, já que são tantas as vozes incorporadas que muitas delas são ativas em nós sem que percebamos sua alteridade (na figura bakhtiniana, são palavras que perderam as aspas).
\end{abstract}

Nesse contexto, estariam Bakhtin, e depois Faraco, fazendo referência à natureza heterogênea e constitutiva da linguagem? É sobre esse viés que seguimos nossa abordagem da e sobre a voz do outro na narrativa. 


\section{A heterogeneidade constitutiva e mostrada}

Em suas pesquisas, Authier-Revuz (1982) descreve as formas da heterogeneidade mostrada no discurso como materialidades que manifestam diferentes modos de negociação do sujeito falante, o que a autora denomina como heterogeneidade constitutiva. A pesquisadora fundamenta seus estudos sobre a heterogeneidade externa no dialogismo de Bakhtin e na psicanálise de Lacan. Segundo Authier-Revuz (1982, p. 2), "as formas sintáticas do DD e do DI exprimem, de maneira unívoca, no plano da frase, um outro ato de enunciação". 0 locutor/narrador funciona como tradutor no discurso indireto, pois, através de suas próprias palavras, faz referência a um outro que é a fonte do dizer relatado. Já no discurso direto, as palavras do outro são produzidas sob um nítido recorte do dizer do locutor/narrador, o qual opera como mero porta-voz. Esses dois modelos sintáticos possibilitam que o locutor expresse com nitidez um discurso alheio, no seu próprio dizer.

Outra modalidade de heterogeneidade, porém, mais complexa, é a mostrada nas formas marcadas da conotação autonímica. Nesse caso, as palavras do outro são inscritas no fio do discurso do locutor/narrador, sem que haja corte na autonímia, embora elas sejam reveladas. Há um deslocamento para outra entidade, aquela que observa as palavras em uso, que pode ser assinalada por meio de marcas linguísticas ou por mecanismos discursivos tais como: aspas, itálico, entoação, em forma de comentário, glosa, retoque ou ajustamento, recebendo diferente estatuto, em relação ao restante do discurso.

Quanto à heterogeneidade constitutiva, Authier-Revuz entende que ela funciona como uma ancoragem essencial no exterior do linguístico, não somente nas formas que oscilam em função das modalidades incertas de seu resgate, mas, es- 
sencialmente, nas formas mais explícitas, mais delimitadas pela presença do outro, no discurso. Como diz a autora, "todo discurso se mostra constitutivamente atravessado pelos outros discursos e pelo discurso do Outro. 0 outro não é um objeto (exterior, do qual se fala), mas uma condição (constitutiva, para que se fale) do discurso de um sujeito falante que não é fonte-primeira desse discurso." (AUTHIER-REVUZ, 1982, p. 56, grifo do autor). É nesse campo que se inscrevem as formas de heterogeneidade mostrada, pois o outro revela-se abertamente, funcionando como objeto do discurso, via mecanismo enunciativo, que, sob as variadas abordagens propostas, revelam-se como um distanciamento do sujeito falante em relação à parte de seu discurso.

A estudiosa defende que, na parte citada de um discurso direto, o sujeito falante não coincide com o locutor/narrador, nem mesmo com o enunciador; já no caso do discurso indireto livre, nem o sujeito falante, nem o locutor/narrador coincidem com o enunciador. Nessa perspectiva, o discurso direto é a forma que se fundamenta na autonímia nítida do distanciamento. Já na parte citada, o locutor/narrador se comporta como porta-voz, como relator de um outro ato de enunciação. Essa aparente clareza revela um modo complexo de mostrar um eu que não está significando, pois coloca o locutor/narrador em posição de exterioridade, em relação aos dizeres que está expressando a seu interlocutor.

Authier-Revuz (1998) explica que, ainda na atualidade, a gramática lida com o discurso do outro de modo bastante tradicional, reconhecendo apenas três formas de representação: o discurso direto, o discurso indireto e o discurso indireto livre. Com um olhar mais crítico, a autora entende que o discurso direto não é tão simples como a gramática o apresenta, chegando mesmo a ser relativamente mais complexo 
do que o discurso indireto, pois não é objetivo e fiel ao dizer, como se costuma pensar. Para a linguista, o discurso indireto não é um discurso direto subordinado, porque não há uma derivação das regras gramaticais, mas diz respeito a duas operações radicalmente distintas do discurso do outro: a citação-relíquia (no uso do discurso direto) e a reformulação-tradução (no uso do discurso indireto). Quanto ao discurso indireto livre, Authier-Revuz (1982) o concebe como uma forma inteira, original, que não deve ser vista em termos de discurso direto-indireto, não sendo também um esquema específico da literatura, pois é frequentemente usado tanto no discurso oral cotidiano, quanto no meio político e na imprensa.

No ponto de vista da autora, as três formas de representar o discurso relatado são importantes, mas elas constituem "uma descrição parcial e empobrecedora do campo da representação do discurso outro no discurso" (AUTHIER-REVUZ, 1998, p. 134). Essa representação é redutora, uma vez que existem outras formas de citá-lo, como é o caso do discurso direto livre e o importante conjunto da modelização do discurso em discurso segundo (segundo fulano; para retomar as palavras de fulano, por exemplo). Conforme já dito, o discurso indireto não corresponde a um discurso subordinado ao discurso direto, uma vez que eles são dois modos distintos de representar um outro ato de enunciação. Enquanto o segundo corresponde a uma operação de citação da mensagem do ato relatado, o primeiro refere-se a uma operação de reformulação. Tal diferença caracteriza o discurso direto como estrutura heterogênea, excepcional na língua, e o discurso indireto como estrutura homogênea, da sintaxe normal da língua. Cabe destacar que essa dualidade pode ser observada no nível semiótico, sintático e na modalidade de enunciação.

A diferença que existe entre o discurso direto livre e o 
discurso indireto livre, complementa a autora, concentra-se no modo diferenciado de funcionamento dos elementos dêiticos. No discurso direto livre, os dêiticos de pessoa, tempo e lugar são, assim como no discurso direto, os do enunciador relatador, funcionando como um discurso direto sem introdutor e sem marca tipográfica. No caso do discurso indireto livre, a questão é mais complexa, pois os dêiticos de pessoa sempre pertencem ao locutor/narrador do enunciado, isto é, assim como acontece no discurso indireto, eles são reformulados em função do locutor/narrador e daquilo que é relatado.

Já os dêiticos de tempo, indicadores verbais ou adverbiais, podem variar. Então, mesmo no plano dos dêiticos, o discurso indireto livre não pode ser visto como um discurso indireto sem elemento introdutório, pois, ao assumir elementos expressivos, exclamativos, avaliativos e modos de dizer do locutor/narrador do discurso relatado, ele surge como uma forma original, bivocal, misturando elementos enunciativos das duas vozes em questão. Nesse viés teórico, Faraco (2009, p. 122) explicita que quando pronunciado, o enunciado espera uma resposta e, por ser heterogeneamente constitutivo, ele contém em si fragmentos de enunciados do outro, já que está "atravessado por uma dialogização interna (a bivocalização nome que recobre os processos pelos quais mais de uma voz e mais de um acento avaliativo ressoam no mesmo enunciado)".

\section{Os efeitos linguístico-semânticos do discurso citado nas crônicas analisadas}

Tendo como base as análises sobre a voz do outro, formuladas por Bakhtin e Authier-Revuz, fomos em busca de respostas às questões que norteiam nosso trabalho. Para construir 
nossa reflexão, selecionamos algumas crônicas que foram publicadas no jornal Zero Hora (RS). Mas, sabemos de antemão não ser possível esgotar o assunto em questão, nem sendo essa nossa intenção, selecionamos três dos textos lidos que, a nosso entender, são significativos por apresentarem diferentes mecanismos que expressam a voz do outro na narrativa curta (ainda que tenham sido publicados há mais de dez anos). Justificamos essa escolha a partir do ponto de vista de que

Com a concepção dialógica da linguagem, a análise histórica de um texto deixa de ser a descrição da época em que o texto foi produzido e passa a ser uma fina e sutil análise semântica, que leva em conta confrontos sêmicos, deslizamentos de sentido, apagamentos de significados, interincompreensões, etc. Em síntese, em Bakhtin, a História não é algo exterior ao discurso, mas é interior a ele, pois o sentido é histórico. Por isso, para perceber o sentido, é preciso situar o enunciado no diálogo com outros enunciados e apreender os confrontos sêmicos que geram os sentidos. Enfim, é preciso captar o dialogismo que o permeia. (FIORIN, 2006, p. 191-192).

Considerando então que nosso foco de análise não é o texto como um todo, procuramos, sem menosprezar o sentido construído pelo conjunto do dizer - via textualidade -, recortar trechos significativos ao funcionamento do discurso citado, nas obras em estudo.

Ao investigar a primeira crônica, escrita por David Coimbra e intitulada "Lendas Urbanas", publicada em 21 de novembro de 2003 (ver anexo), foi possível constatar que os quatro primeiros parágrafos são construídos com a estrutura sintática do discurso indireto, uma vez que o narrador expressa os fatos narrados através do seu ponto de vista. No entanto, a aparente univocidade do narrador no $1^{\text {o }}$ parágrafo é quebrada com a exploração da natureza da heterogeneida- 
de constitutiva da linguagem, pois de modo não marcado (cf. AUTHIER-REVUZ, 1982), o narrador traduz a voz (o ponto de vista) de familiares de ex-governadores e também dá voz a sujeitos não identificados, na medida em que emprega o pronome relativo quem e o pronome indefinido Outros. Ainda que de modo constitutivo, e até por isso mesmo, essas diferentes vozes acabam dando credibilidade ao fato narrado.

Os fantasmas do Palácio Piratini são um capítulo importante das lendas porto-alegrenses. Familiares de ex-governadores atestam sua veracidade. Houve quem tenha visto o vulto magro e alto de Borges de Medeiros suspirando pela ala residencial. Outros depararam com a alma penada gordote de Júlio de Castilhos ainda rondando o gabinete do governador, ainda aferrada ao poder. (1ํo parágrafo).

Esse exemplo do uso da voz do outro representa o dizer de Barros (2003, p. 6), ou seja:

[...] o diálogo é condição da linguagem e do discurso, mas há textos polifônicos e monofônicos, segundo as estratégias discursivas acionadas. No primeiro caso, o dos textos polifônicos, as vozes se mostram; no segundo, o dos monofônicos, elas se ocultam sob a aparência de uma única voz. Monofonia e polifonia de um discurso são, dessa forma, efeitos de sentido decorrentes de procedimentos discursivos que se utilizam em textos, por definição, dialógicos. Os textos são dialógicos porque resultam do embate de muitas vozes sociais; podem, no entanto, produzir efeitos de polifonia, quando essas vozes ou algumas delas deixam-se escutar, ou de monofonia, quando o diálogo é mascarado e uma voz, apenas, faz-se ouvir.

Seguindo nossa análise, no 6ํㅡ e no $11^{\circ}$ parágrafos, o autor emprega o discurso direto, explorando os itens tradicio- 
nais desse uso, cuja estrutura sintática é definida pela gramática normativa (cf. CEGALLA, 1979; BECHARA, 2001), a saber: dois pontos, nova linha e travessão, separando nitidamente o dizer do narrador da voz da personagem:

"Pois o Schimitão viu a Jacqueline e a amiga e disse:

-Vou lá." (6ํㅜ parágrafo)

“-Quero desafio - repete por aí o Schimitão. - Quero as casadas." (11ํo parágrafo)

Há ainda outra variante discursiva no uso da voz de outrem no $7^{0}$ parágrafo. Trata-se do discurso direto livre, pois, ao empregar dois pontos, mas sem travessão, o narrador expressa o dizer dos amigos sobre a atitude de Schimitão:

"Os amigos riram: o Schimitão só falava português, impossível se comunicar com aquelas duas beldades, daquela vez o Schimitão ia se dar mal."

Por fim, os demais parágrafos $\left(8^{\circ}\right.$,, 9 우 $10^{\circ}$ e $12^{\circ}$ ) voltam ao esquema do discurso indireto, uma vez que o narrador passa novamente a traduzir de modo indireto a fala do outro (AUTHIER-REVUZ, 1998).

Já a segunda crônica, de Luís Fernando Veríssimo, cujo título é "A proposta", foi publicada no dia 17 de novembro de 2003 (ver anexo). Nessa narrativa, identificamos exemplos dos esquemas sintáticos via discurso direto, discurso indireto, discurso direto livre e discurso indireto livre, bem como de outros recursos que fazem uso da voz alheia, tais como: aspas, ironia, entoação, reticências e duplo sentido. Enfim, encontramos manifestações da heterogeneidade mostrada e 
constitutiva, conforme vimos com a abordagem psicanalítica de Authier-Revuz (1982).

Ainda que não seja um recurso comum ao gênero crônica, Veríssimo iniciou seu texto através de um discurso indireto livre:

"O russo dera ordens para não ser perturbado no seu quarto de hotel;" e continuou:

"Seriam quatro partidas de xadrez, dele contra o computador, e o Russo já vencera duas." (10o parágrafo)

Diante desses usos, questionamos: Quem é esse outro e como ele se apresenta no discurso narrado? Por que o autor empregou o tempo verbal do pretérito mais que perfeito, quando poderia ter usado o pretérito perfeito, com sentido de ação acabada, factual, ou mesmo um tempo composto? (deu e tinha vencido, por exemplo).

Entendemos que o emprego desses modos verbais produz o efeito de diluir a voz do outro com a do narrador, aqui, no caso, da personagem chamada Russo. Essa estratégia possibilita que a fala do Russo seja mesclada e confundida com a do narrador, diluindo dois atos enunciativos que são vistos como uma única voz. Em vez de se voltar ao exterior, o narrador volta-se ao interior, mostrando o pensamento em processo de elaboração, sob forma de impressão mental, ainda em desenvolvimento (BAKHTIN, 1981).

No que tange ao uso e ao efeito do discurso indireto livre, cabe lembrar aqui a explicação de Fiorin (2006, p. 172, grifo do autor) de que:

No discurso indireto livre, misturam-se duas vozes, a do narrador e a da personagem (em nosso texto, Fabiano). No entanto, faltam elementos lingüísticos, como os dois pontos e o 
travessão no discurso direto ou a conjunção integrante que no indireto, que determinem a fronteira entre as duas. Há dois tons diferentes, que permitem perceber essas duas vozes: o tom mais ou menos neutro da narração e o tom entre colérico e resignado da personagem. Há frases claramente do narrador ('Olhou as cédulas arrumadas na palma, os níqueis e as pratas, suspirou, mordeu os beiços'); outras que, sem dúvida nenhuma, pertencem à personagem ('Para onde? Hem? Tinha para onde levar a mulher e os meninos? Tinha nada!'). Outras, no entanto, poderiam ser de um ou de outro ('Se pudesse mudar-se, gritaria bem alto que o roubavam' poderia ser dita tanto pelo narrador quanto pela personagem). Essa impossibilidade de separação nítida entre a voz do narrador e a da personagem faz do enunciado em discurso indireto livre um enunciado bivocal. Ao misturar sua voz à da personagem, o narrador revela uma 'profunda simpatia' por esse homem submetido a condições 'pré-capitalistas' de trabalho, a esse homem espoliado e degradado. É como se o narrador assumisse como sua a indignação da personagem diante da exploração a que estava sujeita.

Voltando à análise da crônica em estudo, no exemplo:

"Dera ordens na portaria: acima de tudo, nenhum telefonema. E o telefone estava tocando. "Merda! disse o russo, em russo." (1ํo parágrafo).

0 autor recorre ao esquema do discurso direto livre, pois, conforme vimos nos estudos de Authier-Revuz (1982), o narrador relata o discurso do Russo - a personagem - sob o esquema sintático do discurso indireto (sem sujeito aparente); mas, ao mesmo tempo, emprega palavras ditas pelo mesmo e faz uso das marcas gramaticais típicas do discurso direto, tais como dois pontos, aspas e a fala direta ("Merda!"). Além das já citadas, encontramos outra indicação de 
heterogeneidade nesse discurso, ou seja, por meio da ironia, pois havia necessidade de dizer que o Russo falou em russo? Esse dizer leva o interlocutor a se questionar sobre que outros sentidos subjazem a um dizer aparentemente tão óbvio. Temos, então, um dizer do outro não mostrado, isto é, constitutivo, induzindo o interlocutor a interpretar possíveis falas que, na verdade, não são ditas, mas sugeridas, insinuadas, criando efeitos de sentido.

Situação semelhante à anterior observamos em:

“O Russo ligou para a portaria. Não dera ordens para não ser incomodado? Não pedira, expressamente, que não passassem chamadas telefônicas para o seu quarto? Mas, senhor, nenhuma chamada foi passada para seu quarto. Nenhuma! 0 Russo perdeu o sono." (2º parágrafo).

Nesse caso, temos uma composição sintática que combina o uso do discurso direto com o indireto, criando o efeito de sentido que dilui os dizeres de um e de outro, nesse exemplo, a fala do narrador com a das personagens (o Russo e a telefonista do hotel). Nessa variante do discurso direto livre, o narrador se coloca no mesmo nível das personagens, e tanto o uso do ponto de interrogação, no $2^{\circ}$ e no $3^{\circ}$ enunciados, quanto o emprego do pronome de tratamento senhor e do numeral nenhuma, remetem ao discurso direto que, no entanto, são diluídos pela fala do narrador, embora continuem marcados sintaticamente no discurso.

Ainda sobre esse enunciado, cabe questionar: A quem pertence a voz que diz Nenhuma!? Seria da telefonista que reforça seu dizer com Nenhuma! - sendo exclamativa e pondo ênfase na segunda sílaba? Ou seria o Russo que pronuncia 
Nenhuma! - com tom interrogativo? Enfim, pelo modo como foi colocado no enunciado, tal dizer pode ser atribuído tanto a um quanto a outra das personagens. 0 uso da entoação (característica da fala, da voz, da oralidade) poderia resolver esse mistério, pois dependendo da maneira como fosse pronunciado, pertenceria ao Russo ou à telefonista, alterando o sentido construído. No entanto, como se trata de um texto escrito (e literário), a incógnita permanece, funcionando como estratégia de construção de sentido e de superposição de diferentes atos enunciativos, servindo esse enunciado como exemplo da abordagem discursiva dialógica e polifônica de Bakhtin (1981).

Outra questão interessante nesse dizer refere-se à expressão adverbial expressamente. Que outra voz subjaz ao uso desse advérbio de modo? Há um dizer constitutivo ao discurso narrado que denota, a nosso ver, dois aspectos: a voz que repreende, pois houve um pedido expresso, nítido; e a voz que denuncia um ato de negligência, até mesmo de incompetência por parte da telefonista, que tenta defender-se de tal ataque. E indagamos: A quem pertence essa voz e qual seu efeito na produção do sentido do enunciado? Entendemos esse dizer como sendo uma voz interna da personagem chamada Russo, a qual fala sem manifestar-se com nitidez. Trata-se de um dito constitutivo do discurso, por isso soa como um não dito, efeito discursivo que produz sentido, na medida em que leva o interlocutor a interpretar o dizer que subjaz de tal manifestação linguística, em função do modo como é produzido.

0 próximo excerto do $1^{10}$ parágrafo retrata o uso constante das formas direta e indireta nesse texto:

"Atendeu o telefone. Uma voz feminina. Voz de secretária eletrônica, mas ameaçadora. Avisando ao Russo: não vença 


\section{amanhã. 0 quê? Quem é que está falando? Não interessa. Não vença amanhã, senão..."}

Durante toda a informação expressa antes dos dois pontos, ouvimos a fala do narrador, de modo indireto, traduzindo o dizer citado por um outro (cf. AUTHIER-REVUZ, 1982); porém, após os dois pontos (característicos do discurso direto), começa um jogo interlocutivo entre a fala de duas personagens: a secretária eletrônica ("não vença amanhã - Não interessa - Não vença amanhã, senão...") e o Russo (“O quê? Quem está falando?"). Em síntese, temos um diálogo, embora não seja nos moldes sintáticos tradicionais, com nova linha, travessão ou, pelo menos, aspas (cf. BECHARA, 2001); por isso, com base no estudo de Authier-Revuz (1982), denominamos essa construção de discurso direto livre. Ora a voz do narrador, ora a da personagem assume comando no discurso narrado.

No que tange ao sentido, indagamos: que outra voz emerge do dizer que especifica ser uma voz feminina, de secretária eletrônica, no entanto, possui tom ameaçador? Vemos o dizer comum de que a voz feminina tende a ser mais doce do que a masculina, além de que normalmente a expressão registrada na secretária eletrônica tende a ser polida, eis o porquê do uso da conjunção adversativa, ou seja, do mas. Então, a quem pertence esse dizer? Ao narrador? Às personagens? A uma voz comum, universal, do conhecimento popular? Trata-se de um dizer constitutivo do discurso (do já-dito ou da memória discursiva) que, conforme reflexões de Authier-Revuz (1982), embora não seja marcado, faz-se presente, produzindo efeito de sentido ao ser interpretado pelo interlocutor.

Nessa linha investigatória, cabe ainda indagar: Qual é a importância do uso das reticências? Que efeitos elas produ- 
zem no sentido construído? A nosso ver, essa marca linguística possibilita que se abra espaço a uma infinidade de dizeres, o qual pode ser preenchido por diversos discursos, conforme intenção do interlocutor; enfim, essa marca pode servir de recurso e representar uma variedade de vozes que estão implícitas, mas podem ser trazidas à tona pelo leitor da crônica.

Nos trechos que seguem, temos outros exemplos semelhantes ao anterior:

“Mas quem são vocês? pergunta o Russo. Não interessa. Não vença amanhã, senão...; Podemos fazer um acerto, disse a voz. Quanto você quer para entregar o jogo?; O Russo reagiu com indignação. Minha honra não está à venda! Calma, disse a voz." (1ํo parágrafo)

Como se pode ver, continua o jogo interlocutivo entre a fala direta e indireta (do narrador e das personagens), porém, com um elemento diferenciador: agora há um marcador típico do discurso direto, o verbo dicendi (pergunta e disse), indicador linguístico que não se fazia presente no exemplo estudado anteriormente. Ainda no $2^{\circ}$ parágrafo, temos outra voz alheia, no longo trecho que vai de: "Se você vencer o segundo e o terceiro jogo, [...]" até "Isso nós garantimos", pertencente ao e-mail que o Russo lê no seu notebook.

Veríssimo finaliza sua crônica com uma construção típica do gênero: primeiro emprega o discurso indireto, fazendo uma tradução da voz do outro; depois, o discurso direto, dando ao outro espaço para que ele fale com suas próprias palavras, servindo, assim, de seu porta-voz, aqui, no caso, do elevador: 
"No dia seguinte, descendo no elevador do hotel a caminho do terceiro jogo, o Russo ouviu uma voz. Era o elevador perguntando: “Como é, pensou na nossa proposta?" (5ํ parágrafo).

Ainda nesse texto, vale questionar: a quem o pronome nós se refere nessas passagens da crônica "A proposta"? Que voz ou quais vozes ele representa?

"Nós o perseguiremos até seus últimos dias.; Se tentar mudar de nome, nós descobriremos e anularemos o novo nome também."; “Isso nós garantiremos.” (todos no $2^{\circ}$ parágrafo)

A presença do pronome nós é tão marcante que a própria personagem (o Russo) questiona: "Mas quem são vocês? pergunta o Russo.". De início, só havia a voz da secretária eletrônica que, embora anônima, era individual; no entanto, de repente, essa mesma fala passa a ser um plural, um conjunto de vozes, uma organização, talvez. A mudança acontece sem aviso, como algo natural no desenrolar da narrativa, funcionando como estratégia de produção de sentido, pois dá voz a um outro coletivo.

Para finalizar o estudo desta narrativa, recortamos um enunciado no qual Veríssimo explora o uso do discurso indireto, quando o narrador funciona como tradutor do discurso citado, bem como do discurso indireto livre:

“O Russo perdeu a paciência. Não sabiam com quem estavam tratando! Digitou no notebook que as ameaças não o intimidariam, que derrotaria o computador no xadrez mais duas vezes e provaria que a mente humana ainda não tinha 
substituto à altura, que por mais que aperfeiçoassem o computador, a máquina não venceria o Homem, e..." ( $3^{\circ}$ parágrafo).

Com exceção do $2^{\circ}$ enunciado, que apresenta características do discurso indireto livre, pois deixa aflorar de modo mais nítido a voz da personagem (inclusive seus sentimentos), mostrando emoção, via ponto de exclamação e pelo uso do tempo verbal no pretérito imperfeito, os demais enunciados se manifestam como tradutores do dizer do Russo, por meio do discurso indireto.

Por fim, a terceira e última crônica foi escrita por Martha Medeiros e publicada em 12 de novembro de 2003, sob o título "Outras coisas" (ver anexo). Nessa narrativa, identificamos o uso frequente do discurso indireto, opção comum a esse gênero, pois emprega o esquema em que o narrador traduz o dizer do outro, usando suas próprias palavras, indiretamente. Conforme vimos com Bakhtin (1981), ora sem sujeito aparente, no caso do discurso indireto; ora diluindo as fronteiras, no caso do discurso indireto livre.

Alguns dos mecanismos de heterogeneidade mostrada utilizados pela cronista, com o intuito de dar a voz ao outro, são os parênteses e as aspas (AUTHIER-REVUZ, 1982). No $1^{\text {o }}$ parágrafo, por exemplo, a autora/narradora abre espaço à fala de Lobão, cantor e editor da revista em questão, por meio da citação do trecho de uma de suas músicas: "me chama/ me chamaaaaa", fazendo alusão a seu dizer na referida canção. Nesse caso, temos um exemplo do uso do recurso da intertextualidade para dar voz ao outro, pois, conforme Fiorin (2006), ao analisar a poesia Satélite, de Manuel Bandeira, que faz referência a um verso da poesia Plenilúdio, de Raimundo Correa (FIORIN, 2006, p. 180), 
O texto de Raimundo Correia tem uma existência como texto fora do texto de Bandeira. É só nesses casos que se deve falar em intertextualidade. Ela é o processo da relação dialógica não somente entre duas 'posturas de sentido', mas também entre duas materialidades linguísticas.

Ainda no primeiro parágrafo, a autora/narradora volta a fazer fluir a voz de Lobão, agora, através da modalidade sintática do discurso direto livre, usando dois pontos e ponto de interrogação:

"Agora é ele (Lobão) quem chama para uma reflexão: vamos passar o resto da vida cultuando apenas hits? 0 que mais se está produzindo no Brasil que a gente não enxerga?"

Na sequência, as aspas voltam a ser usadas no $4^{\circ}$ o parágrafo, em "país da música", uso que, além de chamar a atenção sobre tal denominação, questionando-a, traz uma carga de ironia, na qual subjaz um ponto de vista de depreciação. Além desses casos, pode-se observar um discurso citado por trás do uso das aspas em "produto", no último parágrafo. Do uso dessas aspas subjaz uma voz que critica o modo como o mercado e o público em geral lidam com o sucesso e a produção artística.

Há ainda ironia nesse dizer, pois existem talentos que acabam sendo perdidos, em função da maneira como a sociedade lida com seus (futuros) artistas. Algumas vozes, explica Faraco (2009), acabam sendo constitutivas em nossa memória discursiva como palavras do outro e, nessas condições, acabam sendo bivocalizadas em nossos enunciados, ou seja, o dizer de outrem e nossa perspectiva sobre sua fala inter-relacionam-se, confundindo-se entre si. Em síntese, as vozes do outro "são citadas direta ou indiretamente, são aceitas incondicionalmente 
ou ironizadas, parodiadas, polemizadas aberta ou veladamente, estilizadas, hibridizadas" (FARACO, 2009, p. 86).

Cabe ainda destacar as duas situações em que o narrador cede espaço (força, segundo BAKHTIN, 1981) para a voz da revista Outra coisa, inicialmente, via discurso direto livre:

“... mas o que a revista se propõe a dizer é: vamos direcionar nossos ouvidos e olhos também para aqueles que não fazem parte do mainstream." (4ํㅜ parágrafo)

e, depois, por meio do discurso indireto livre:

“O que a revista quer é divulgar pensamentos vários, que podem vir de pessoas com ou sem contrato, com ou sem nome na praça, tanto faz, porque não é este o critério." (4ํㅗำ parágrafo)

Por fim, percebemos a voz do outro através do uso da expressão a gente e do pronome nós (oculto), no 5o parágrafo:

“ 0 comum é a gente pensar que se mal conseguimos consumir a enxurrada de novos artistas que são despejados no mercado, imagine ainda ter tempo para pesquisar nomes alternativos.",

recursos linguísticos que pluralizam o dizer, protegendo, ou mesmo encobrindo, a responsabilidade da autora/narradora diante do que é dito. 


\section{Considerações Finais}

A análise dos efeitos linguístico-discursivos produzidos pelo discurso citado nas crônicas selecionadas reforçou o dizer de Bakhtin (1981) de que a literatura, por sua natureza criativa, tende a ser mais flexível nos modos de dar voz ao outro nos seus textos. Diferentemente do esperado, encontramos pouco uso do esquema sintático via discurso direto, sendo que os discursos: indireto (fala traduzida pela voz do narrador), direto livre e indireto livre (jogo de força na relação entre o dizer do narrador e das personagens) foram esquemas mais recorrentes nas crônicas investigadas. Ao comparar o uso dos dois discursos livres - direto e indireto -, observamos que o primeiro apresenta marcas mais nítidas do que o segundo, embora os dois se expressem livremente, isto é, manifestem constitutivamente a voz do outro.

0 estudo da voz do outro nas três narrativas mostrou que o autor/narrador concede a fala tanto de modo mostrado quanto constitutivo. Ora o narrador afasta-se mais do outro, mostrando-o; ora aproxima-se dele, envolvendo-o em seu dizer, de modo constitutivo, deixando-o velado. No nosso objeto de estudo, encontramos exemplos de usos da heterogeneidade mostrada e constitutiva, pois esse é um recurso linguísticodiscursivo rico no dizer das crônicas jornalísticas, dando-lhes margem à criatividade. Conforme vimos ao longo da análise, encontramos usos de aspas, parênteses, inferências, reticências e ironia, além dos esquemas com os discursos livres, já citados.

Ainda que tenhamos estudado somente três crônicas, amostras suficientes para nossa proposta qualitativa e não quantitativa, podemos dizer que o discurso do outro se faz presente nesse gênero e desempenha papel essencial no sentido produzido. Às vezes, o discurso do outro é manifestado 
de forma marcada, mostrada (isso acontece quando o narrador afasta-se do dizer do outro, separando-o do seu próprio dizer); outras vezes, ele é expresso de modo constitutivo, velado (quando o narrador se aproxima e dilui sua fala na voz do outro), ou não, dependendo do efeito semântico que o autor deseja dar a seu texto.

\section{REFERÊNCIAS}

AUTHIER-REVUZ, J. Palavras incertas: as não-coincidências do dizer. Campinas: UNICAMP, 1998.

Heterogeneidade mostrada e heterogeneidade constitutiva: elementos para uma abordagem do outro no discurso. In DRLAV (Documentation et Recherche en Linguistique Allemande-Vincennes), Paris, n. 26, 1982.

BAKHTIN, M. Problemas da poética de Dostoiévski. Tradução de P. Bezerra. Rio de Janeiro: Forense Universitária, [1929] 2002.

Estética da criação verbal. Tradução de P. Bezerra. São Paulo: Martins Fontes, 1992.

BAKHTIN, M.; VOLOCHÍNOV, V. N. Marxismo e filosofia da linguagem. Tradução de M. Lahud e Y. Frateschi Vieira. São Paulo: Hucitec, 1981.

BARROS, D. L. P. de. Dialogismo, polifonia e enunciação. In BARROS, D. L. P. de; FIORIN, J. L. (Org.). Dialogismo, polifonia, intertextualidade. 2. ed. São Paulo: Ed. da Edusp, 2003.

BRAIT, B. Análise e teoria do discurso. In BRAIT, B. (Org.). Bakhtin: outros conceitos-chave. São Paulo: Contexto, 2006. p. 9-32. 
. Estilo. In BRAIT, B. (Org.). Bakhtin: conceitos-chave. São Paulo: Contexto, 2005. p. 72-102.

BECHARA, E. Moderna gramática portuguesa. Rio de Janeiro: Lucerna, 2001.

CEGALLA, D. P. Novíssima gramática de língua portuguesa. São Paulo: Nacional, 1979.

COIMBRA, D. Lendas Urbanas. Zero Hora, 21-11-2003.

FARACO, C. A. Linguagem e diálogo: as idéias lingüísticas do Círculo de Bakhtin. São Paulo: Parábola, 2009.

FIORIN, J. L. Intertextualidade e interdiscursividade. In BRAIT, B. (Org.). Bakhtin: outros conceitos-chave. São Paulo: Contexto, 2006. p. 157-193.

MEDEIROS, M. Outras coisas. Zero Hora, 12-11-2003.

VERÍSSIMO, L. F. A Proposta. Zero Hora, 17-11-2013.

\section{ANEXOS}

\section{Lendas Urbanas}

\section{David Coimbra}

Os fantasmas do Palácio Piratini são um capítulo importante das lendas porto-alegrenses. Familiares de ex-governadores atestam sua veracidade. Houve quem tenha visto o vulto magro e alto de Borges de Medeiros suspirando pela ala residencial. Outros depararam com a alma penada gordote de Júlio de Castilhos ainda rondando o gabinete do governador, ainda aferrada ao poder. 
Existe também a lenda da gangue do Halls preto. Mulheres vestidas com minissaias minúsculas e decotes vertiginosos adejando pela noite à caça de homens que serão primeiro seduzidos, depois submetidos à prática ardida da sessão de Halls preto. Terrível.

E há o Schimitão. Esse não é seu verdadeiro nome, mas preciso lhe preservar a identidade. Sempre sorridente, bem vestido e simpático, o Schimitão é tido como irresistível.

Décadas atrás, no Rio, quis a Providência que o Schimitão estivesse na mesma festa em que estavam Jacqueline Bisset e uma amiga dela, também atriz, também lindíssima.

Ah, preciso confessar que, na adolescência, eu andava com a foto da Jacqueline Bisset na carteira. Jacqueline Bisset, tão perfeita, tão inatingível, um anjo distante e justamente graças a essa distância é que ela redimia a vida e suas contingências: havendo Jacqueline Bisset, havia perfeição. Quando tudo parecia estar ruindo, eu sacava a foto da Jacqueline Bisset e pensava: o mundo é bom, nele está a Jacqueline Bisset.

Pois o Schimitão viu a Jacqueline e a amiga e disse:

- Vou lá.

Os amigos riram: o Schimitão só falava português, impossível se comunicar com aquelas duas beldades, daquela vez o Schimitão ia se dar mal.

O Schimitão foi mesmo assim. Duas horas depois estava na piscina com a amiga da Jacqueline Bisset. De roupa e tudo.

Ontem, soube que o Schimitão está de volta. Tem circulado pelos bares da cidade armado com seu olhar infalível e com uma tenebrosa ameaça entre os dentes perfeitos: ele, agora que está na fronteira dos 50 anos, desenvolveu uma preferência pelas mulheres casadas.

- Quero desafio - repete por aí o Schimitão. - Quero as casadas. 
Alguns maridos já estão montando esquemas de segurança para se proteger do Schimitão. Eu não me preocupo. Mas não por não ser casado. É que, naquela piscina carioca, não estava a Jacqueline Bisset. Sim, senhor: o Schimitão não conspurcou a Jacqueline Bisset. (Porto Alegre, 21 de novembro de 2003).

\section{A proposta}

Luís Fernando Veríssimo

O Russo dera ordens para não ser perturbado no seu quarto de hotel. Seriam quatro partidas de xadrez, dele contra o computador, e o Russo já vencera duas. Precisava estar em forma para as outras duas. Precisava descansar. Não atenderia telefonemas de quem quer que fosse. Dera ordens na portaria: acima de tudo, nenhum telefonema. E o telefone estava tocando. "Merda!" disse o Russo, em russo. Atendeu o telefone. Uma voz feminina. Voz de secretária eletrônica, mas ameaçadora. Avisando o Russo: não vença amanhã. 0 quê? Quem é que está falando? Não interessa. Não vença amanhã, senão...

O Russo ligou para a portaria. Não dera ordens para não ser incomodado? Não pedira, expressamente, que não passassem chamadas telefônicas para o seu quarto? Mas senhor, nenhuma chamada foi passada para o seu quarto. Nenhuma! O Russo perdeu o sono, ligou seu notebook. Aproveitaria para reestudar alguns lances. Viu que havia uma mensagem para ele no notebook. Um e-mail. Outro aviso. Se você vencer o segundo e o terceiro jogo, não tem idéia do que pode lhe acontecer. Nós os perseguiremos até os seus últimos dias. Você será varrido de todos os bancos de dados do planeta. Tentará fa- 
zer transações bancárias e não conseguirá. Não poderá mais viajar. Nenhum terminal de computador de aeroporto, em nenhum lugar do mundo, aceitará o seu nome. Se tentar mudar de nome, nós descobriremos e anularemos o novo nome também. Seus cartões de crédito não serão mais reconhecidos. Todas as suas senhas falharão. Os videogames não obedecerão aos seus comandos. 0 mesmo acontecerá a todos os seus descendentes, até o fim dos tempos. Isso nós garantimos. Mas quem são vocês? pergunta o Russo. Não interessa. Não vença amanhã, senão...

O Russo perdeu a paciência. Não sabiam com quem estavam tratando! Digitou no notebook que as ameaças não o intimidaram, que derrotaria o computador no xadrez mais duas vezes e provaria que a mente humana ainda não tinha substituto à altura, que por mais que aperfeiçoassem o computador, a máquina não venceria o Homem, e...

Nisso, o telefone tocou de novo. A mesma voz de secretária eletrônica, mas desta vez num tom conciliador. Podemos fazer um acerto, disse a voz. Quanto você quer para entregar o jogo? O Russo reagiu com indignação. Minha honra não está à venda! Calma, disse a voz. Pense no assunto. Se você aceitar entregar o jogo, todas as máquinas dispensadoras de dinheiro do mundo estarão à sua disposição, para a retirada que você quiser. Sem limites, e para sempre. Basta você dizer quem é e quanto quer e elas despejarão dinheiro aos seus pés. Pense no assunto.

No dia seguinte, descendo no elevador do hotel a caminho do terceiro jogo, o Russo ouviu uma voz. Era o elevador perguntando: “Como é, pensou na nossa proposta?". (Porto Alegre, 17 de novembro de 2003). 


\section{Outras Coisas}

Martha Medeiros

No início deste mês foi lançado mais uma revista no Brasil: Outra coisa, editada no Rio pela Net Records e cujo editor é o Lobão ("me chama/me chamaaaaa"). Lobão, em seu ritmo mais conhecido, queria ser chamado. Agora é ele quem chama para uma reflexão: vamos passar o resto da vida cultuando apenas hits? 0 que mais se está produzindo no Brasil que a gente não enxerga?

A revista, que é bimestral e virá sempre com um CD encartado, é um espaço para músicos independentes e outras independências. Pretende divulgar o lado outsider da cena cultural do país, que é tão rica quanto desconhecida. Ao abrir a página que traz resenhas de discos, me senti cidadã da Eslováquia.

Nunca tinha ouvido falar em Matanza, Barrosinho \& Maracatamba, Eddie, Mylene, BNegão, Valeria Sattamini, Rogério Skylab. Estão aí, lançam discos, fazem shows. Existem, mas não existem comercialmente. E não existir comercialmente, nos tempos de hoje, é quase óbito.

0 comum é a gente pensar que, se mal conseguimos consumir a enxurrada de novos artistas que são despejados no mercado, imagine ainda ter tempo para pesquisar nomes alternativos. Erro brutal, que mantém à margem centenas de artistas com novas propostas, novos estilos, uma pluralidade que incrementaria esse nosso "país da música" e que nos daria uma identidade menos encaixotada, menos embalada pra presente. Quantas outras Marias Ritas haverão no Brasil? Ok, dizer que há uma dúzia de Marias Ritas por aí é insanidade, a moça é pérola rara que veio de uma ostra mais rara ainda, mas 
o que a revista se propõe a dizer é: vamos direcionar nossos ouvidos e olhos também para aqueles que não fazem parte do mainstream.

Bom, Outra coisa não tem este tom lamuriento, apenas celebra o lado B da cultura nacional, a faixa que não tocou no rádio, o assunto que não foi pautado, a idéia que ficou de fora. Não quer dizer que abrigue uma turma de desalojados, e também que tudo o que recomenda seja espetacular. 0 que a revista quer é divulgar pensamentos vários, que podem vir de pessoas com ou sem contrato, com ou sem nome feito na praça, tanto faz, porque não é este o critério. Não é briga. Não é a guerra do bem contra o mal, do artista que foi alçado à fama contra o que não foi considerado um bom "produto", nada desse papo rançoso e ressentido. É apenas mais um veículo de informação direcionado a um público que tem curiosidade extrema, que tem carência de diversidade, que quer saber o que mais há por aí. Me orgulho de ser uma das colunistas da revista e de ter esta oportunidade de discutir sobre o acomodamento com que recebemos e festejamos tudo o que colocam prontinho no nosso colo, já que estamos sempre cansados para procurar outra coisa. (Porto Alegre, 12 de novembro de 2003).

Artigo recebido em março de 2015 e aprovado em junho de 2015.

Disponível em: http://seer.fclar.unesp.br/casa 